\title{
Perencanaan Perkuatan Dinding Kolam Pelabuhan dan Penggunaan Material Dredging sebagai Material Timbunan pada Area Perluasan Dermaga Proyek RDMP-RU V Balikpapan
}

\author{
Muhammad Ivan Adi Perdana, Yudhi Lastiasih, dan Noor Endah \\ Departemen Teknik Sipil, Fakultas Teknik Sipil dan Perencanaan, Institut Teknologi Sepuluh Nopember (ITS) \\ e-mail: yudhi_lastiasih@ce.its.ac.id
}

\begin{abstract}
Abstrak-Proyek RDMP-RU V PT. Pertamina Balikpapan meliputi pembangunan sisi darat dan laut. Di sisi darat akan digunakan sebagai perluasan dermaga untuk lahan parkir kendaraan, yang dibangun diatas tanah clayey silt. Tanah tersebut memiliki pemampatan yang cukup besar dan berlangsung sangat lama serta memiliki daya dukung yang kecil. Sedangkan kawasan sisi laut terdapat dredging area yang menghasilkan material kerukan. Material tersebut biasanya tidak dipergunakan lagi dan dibuang disuatu tempat. Hal ini akan lebih menguntungkan apabila dimanfaatkan sebagai material timbunan disisi darat. Dalam tugas akhir ini akan direncanakan penimbunan tanah pada sisi darat yang dibangun di atas tanah lunak, sehingga diperlukan perencanaan perbaikan tanah. Metode yang dapat digunakan dalam perencanaan perbaikan tanah adalah metode preloading dengan prefabricated vertical drain (PVD) untuk mempercepat pemampatan. Dengan adanya timbunan tersebut perlu dibangun konstruksi dinding penahan tanah untuk mencegah kelongsoran. Berdasarkan hasil analisis pada tugas akhir ini disimpulkan bahwa kondisi tanah dasar memiliki tebal lapisan mampu mampat sedalam 25 m. Material dredging dapat digunakan sebagai material timbunan. Tinggi awal timbunan (H-Inisial) yaitu $5.28 \mathrm{~m}$ (Zona 1) dan 4.59 m (Zona 2). Besarnya pemampatan konsolidasi (Sc) adalah 1.42 $\mathrm{m}$ (Zona 1) dan $1.23 \mathrm{~m}$ (Zona 2). Pemasangan PVD direncanakan menggunakan pola segiempat dengan spasi $1.2 \mathrm{~m}$ yang ditanam sedalam 25 meter dengan waktu pemampatan konsolidasi (U) 90 $\%$ selama 23 minggu. Alternatif perkuatan dinding menggunakan secant pile dengan panjang $27.6 \mathrm{~m}$ (zona 1) dan $26.3 \mathrm{~m}$ (zona 2). Total biaya konstruksi penimbunan hingga perencanaan secant pile sebesar Rp8.135.487.283,-.
\end{abstract}

Kata Kunci-Material Dredging, Preloading, Prefabricated Vertical Drain (PVD), Sheet Pile, Soldier Pile, Secant Pile.

\section{PENDAHULUAN}

$\mathrm{P}$ ERENCANAAN pembangunan proyek pelabuhan Refinery Development Masterplan Program (RDMP) Refinery Unit (RU) V PT. Pertamina Balikpapan meliputi pembangunan sisi darat dan sisi laut. Kawasan sisi darat akan digunakan sebagai perluasan dermaga untuk lahan parkir kendaraan seluas $7527 \mathrm{~m}^{2}$ yang akan dibangun perkerasan jalan, sehingga membutuhkan penimbunan tanah dengan elevasi yaitu +4 sampai dengan +4.5 mLWS. Sedangkan kawasan sisi laut terdapat dredging area yang direncanakan dengan kedalaman -9 mLWS dan -3 mLWS.

Perencanaan sisi darat dan sisi laut tersebut dibangun diatas tanah lunak. Berdasarkan data tanah secara umum memiliki jenis tanah clayey silt. Tanah tersebut memiliki pemampatan yang cukup besar dan berlangsung sangat lama serta memiliki daya dukung yang kecil.

Berdasarkan latar belakang dan permasalahan diatas, pada tugas akhir ini akan direncanakan penimbunan tanah pada sisi darat yang dibangun di atas tanah lunak, sehingga diperlukan perencanaan perbaikan tanah. Metode yang dapat digunakan dalam perencanaan perbaikan tanah adalah metode preloading dan pemasangan prefabricated vertical drain

(PVD) untuk mempercepat pemampatan. Di sisi laut, pada kawasan dredging menghasilkan material kerukan yang biasanya tidak dipergunakan lagi dan dibuang disuatu tempat. Dengan adanya material dredging dapat digunakan sebagai material timbunan pada area perluasan dermaga karena lebih ekonomis dan tidak perlu membuka lahan baru untuk pembuangan material dredging. Dengan adanya perluasan dermaga, perlu dibangun konstruksi dinding penahan tanah untuk mencegah kelongsoran. Perkuatan yang dapat digunakan sebagai alternatif adalah sheet pile, secant pile dan soldier pile. Dari ke 3 alternatif dinding tersebut dipilih yang paling murah dan efektif sebagai dinding kolam pelabuhan.

\section{METODOLOGI}

Metode yang digunakan dalam perencanaan adalah sebagai berikut:

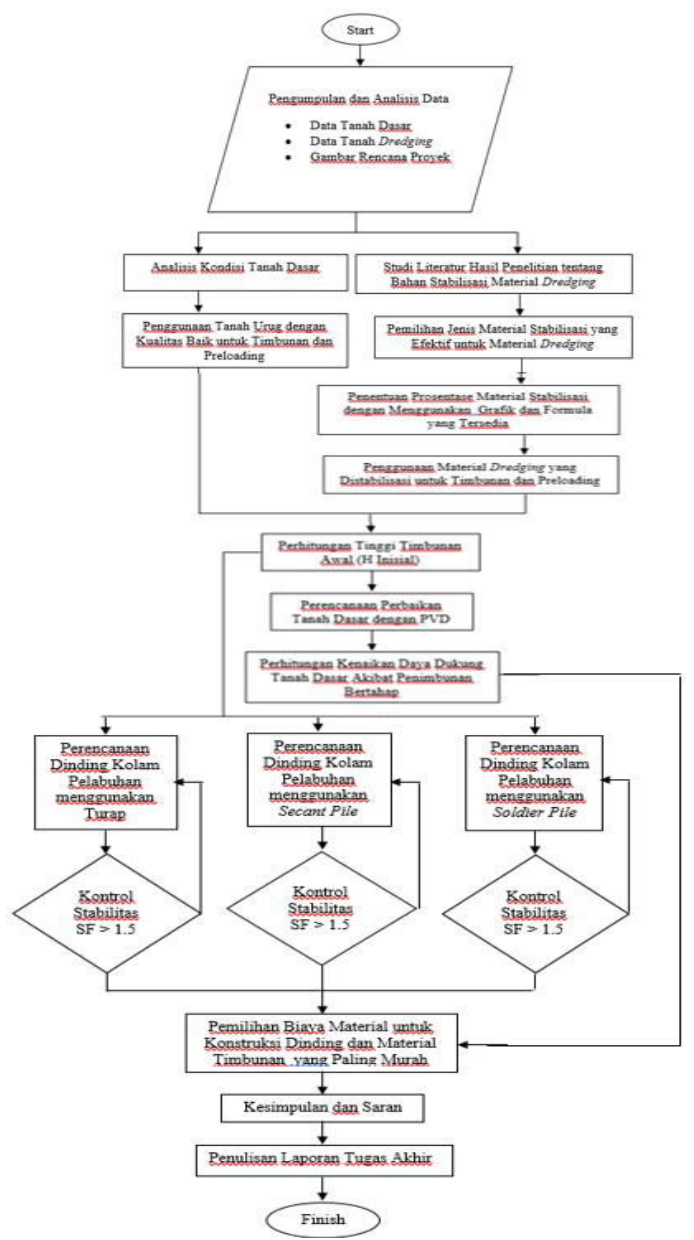

Gambar 1. Bagan Alir Tugas Akhir 


\section{HASIL DAN PEMBAHASAN}

\section{A. Analisis Data}

\section{Data Tanah Dasar}

Data tanah dasar yang digunakan dalam Tugas Akhir ini adalah data sekunder yang berupa Borlog, Standard Penetration Test (SPT) dan hasil test laboratorium. Terdapat 6 titik bor yang dilakukan hingga kedalaman $60 \mathrm{~m}$. Data borlog SPT dan hasil laboratorium dari 6 titik bor tersebut dapat dilihat pada [1].

Data tanah yang dipakai ditentukan dengan menggunakan metode statistik distribusi dengan derajat kepercayaan (Confidence Level) 90\%. Dari setiap parameter tanah dikelompokkan berdasarkan kedekatan nilai parameter dan kedalaman sehingga tiap kelompok tersebut dijadikan satu nilai dengan metode statistik distribusi. Metode statistik distribusi menggunakan tabel distribusi-t (Tail Distribution).

Berdasarkan hasil analisis didapat tebal lapisan mampu mampat sedalam $25 \mathrm{~m}$ dengan 3 meter awal lapisan tanah silty sand dan 22 meter dibawahnya adalah lapisan tanah clayey silt. Rekapitulasi data tanah di titik bor A6 dari hasil analisis menggunakan metode statistik distribusi dan rumus korelasi dapat dilihat pada Tabel 1.

\section{Material Timbunan}

Material timbunan yang digunakan adalah tanah hasil dredging pada proyek RDMP RU V PT. Pertamina Balikpapan. Data tanah yang digunakan sebagai acuan parameter dredging adalah data tanah titik A2 dimana pada kedalaman -9.0 mLws jenis tanahnya silty sand dengan konsistensi very loose to loose. Berdasarkan analisis parameter material timbunan, maka tidak perlu dilakukan stabilisasi karena sesuai persyaratan timbunan [2], sehingga sudah cukup bagus digunakan sebagai tanah timbunan Hasil analisis data tanah dredging dapat dilihat pada tabel 2 .

Tabel 1.

Rekapitulasi Data Tanah Dasar Hasil Perhitungan Statistik

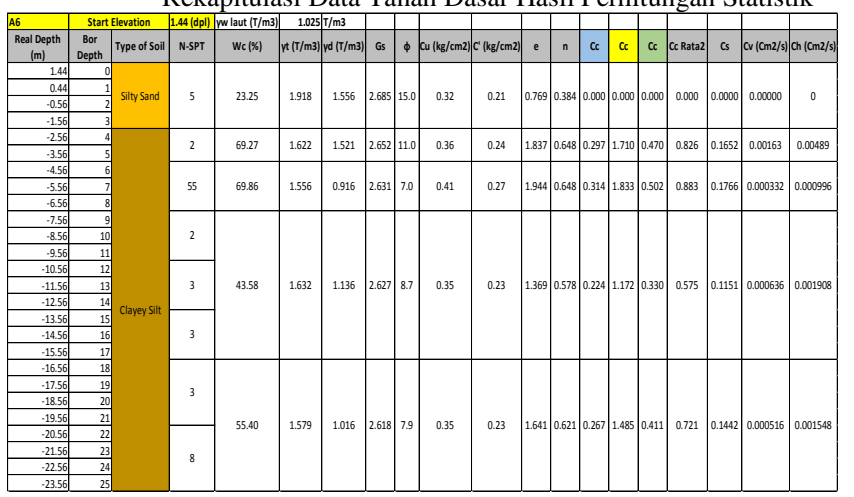

Tabel 2.

Rekapitulasi Data Tanah Dredging Hasil Perhitungan Statistik

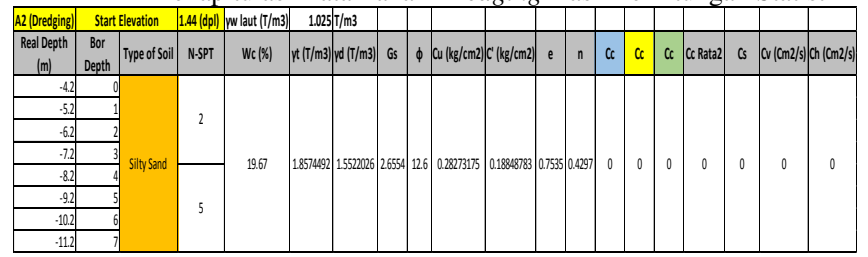

\section{Zona Penimbunan}

Dalam perencanaan penimbunan terdapat 2 zona penimbunan yaitu Zona 1 (satu) dengan tinggi elevasi akhir +4.5 m dan Zona 2 (dua) dengan elevasi akhir +4 m. Kedua timbunan tersebut direncanakan diatas muka tanah dengan elevasi $+1.44 \mathrm{~m}$ dengan data tanah A6. Lokasi penimbunan dan dimensi timbunan dapat dilihat pada Gambar 2.

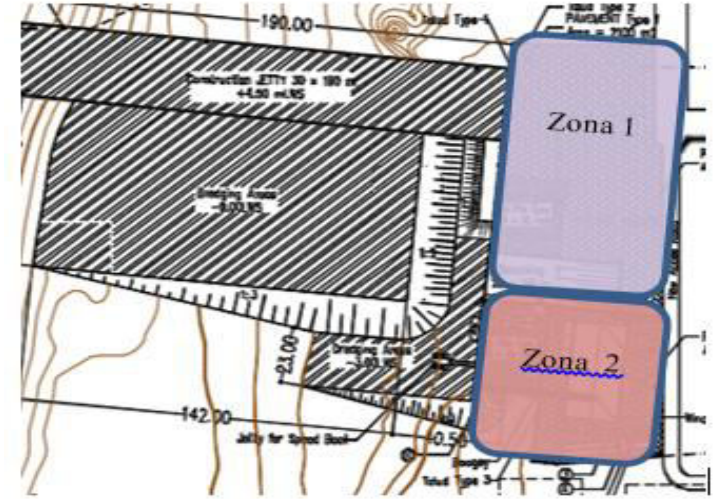

Gambar 2. Zona Penimbunan pada Proyek RDMP RU V PT. Pertamina Balikpapan.

\section{Data untuk Desain dan Analisis}

Data Beban

Beban untuk perencanaan timbunan adalah beban perkerasan dan beban traffic alat berat. Tebal perkerasan 20 $\mathrm{cm}$ dengan menggunakan perkerasan rigid (rigid pavement). Beban traffic alat berat diasumsikan sebesar $1 \mathrm{~T} / \mathrm{m}^{2}$. Total beban perkerasan $1.48 \mathrm{~T} / \mathrm{m}^{2}$.

B. Perencanaan Timbunan Preloading dan Perbaikan Tanah Dasar

\section{Timbunan Preloading}

Penimbunan di daerah sisi darat Proyek RDMP-RU V PT. Pertamina Balikpapan direncanakan sebagai timbunan preloading. Timbunan preloading akan turun bersamaan dengan pemampatan tanah dasar hingga mencapai tinggi final rencana yaitu $3.06 \mathrm{~m}$ untuk Zona 1 dan $2.56 \mathrm{~m}$ untuk Zona 2. Tinggi beban timbunan direncanakan bervariasai dengan tinggi $1 \mathrm{~m}, 2 \mathrm{~m}, 3 \mathrm{~m}, 4 \mathrm{~m}$, dan $5 \mathrm{~m}$. Variasi beban timbunan dapat dilihat pada Tabel 3.

Tabel 3.

Variasi Beban Timbunan (q) untuk masing-masing $H$ timbunan

\begin{tabular}{|c|c|c|c|}
\hline $\begin{array}{c}\text { H beban } \\
\text { Timbunan }(\mathbf{m})\end{array}$ & $\begin{array}{c}\text { H Bongkar } \\
(\mathbf{m})\end{array}$ & $\begin{array}{c}\text { H Timbunan } \\
(\mathbf{m})\end{array}$ & $\mathbf{q}(\mathbf{t} / \mathbf{m} \mathbf{2})$ \\
\hline 1 & 0.797 & 1.797 & 3.337 \\
\hline 2 & 0.797 & 2.797 & 5.195 \\
\hline 3 & 0.797 & 3.797 & 7.052 \\
\hline 4 & 0.797 & 4.797 & 8.910 \\
\hline 5 & 0.797 & 5.797 & 10.767 \\
\hline
\end{tabular}

Pemampatan Segera (Si)

Hasil perhitungan nilai pemampatan segera dapat dilihat pada Tabel 4.

Tabel 4.

Rekapitulasi Nilai Pemampatan Segera untuk masing-masing variasi beban timbunan pada kedua Zona.

\begin{tabular}{|r|r|r|r|r|r|r|}
\hline$q(t / m 2)$ & $h(m)$ & $E(M N / m 2)$ & $E(k N / m 2)$ & $E^{\prime}(k N / m 2)$ & \multicolumn{1}{c|}{$\mu$} & \multicolumn{1}{c|}{$S i(m)$} \\
\hline 3.337 & 3 & 11.5 & 11500 & 13396.42357 & 0.233 & 0.0074739 \\
\hline 5.195 & 3 & 11.5 & 11500 & 13396.42357 & 0.233 & 0.01163347 \\
\hline 7.052 & 3 & 11.5 & 11500 & 13396.42357 & 0.233 & 0.01579305 \\
\hline 8.910 & 3 & 11.5 & 11500 & 13396.42357 & 0.233 & 0.01995263 \\
\hline 10.767 & 3 & 11.5 & 11500 & 13396.42357 & 0.233 & 0.02411221 \\
\hline
\end{tabular}

\section{Pemampatan Konsolidasi (Sc)}

Perhitungan Pemampatan konsolidasi menggunakan pada saat kondisi overconsolidated karena nilai OCR $>1$ dan $\left(\sigma_{0}{ }^{\prime}+\right.$ $\Delta \sigma)>\sigma_{\mathrm{c}}{ }^{\prime}$.

Perhitungan Tinggi Timbunan Awal (H-Inisial) dan Akhir (HFinal)

Perhitungan tinggi perhitungan awal menggunakan langkah-langkah pada [3], sehingga didapat nilai tinggi timbunan awal tiap masing-masing variasi beban. Rekapitulasi perhitungan total pemampatan, nilai $\mathrm{H}$ Inisial dan $\mathrm{H}$ Final 
untuk semua variasi beban pada kedua zona, dapat dilihat pada Tabel 5.

Tabel 5.

Rekapitulasi Perhitungan H-Inisial, H-Final, dan Sc; (a) Zona 1;(b) Zona 2

(a)

\begin{tabular}{|c|c|c|c|c|c|c|c|}
\hline $\mathrm{Htimb}(\mathrm{m})$ & $q$ total $\left(t \mathrm{~m}^{2}\right)$ & $H$ inisial $(m)$ & $\begin{array}{c}H \text { bongkar } \\
(\mathrm{m})\end{array}$ & Sc & $\mathrm{Si}$ & S Total & $H$ final $(m)$ \\
\hline 1 & 3.337 & 2.092 & 0.797 & 0.527 & 0.0074739 & 0.535 & 0.760 \\
\hline 2 & 5.195 & 3.299 & 0.797 & 0.898 & \begin{tabular}{|c|c|}
0.01163347 \\
\end{tabular} & 0.910 & 1.592 \\
\hline 3 & 7.052 & 4.478 & 0.797 & 1.219 & 0.01579305 & 1.235 & 2.447 \\
\hline 4 & 8.910 & 5.636 & 0.797 & 1.501 & 0.01995263 & 1.521 & 3.318 \\
\hline 5 & 10.767 & 6.778 & 0.797 & 1.755 & 0.02411221 & 1.779 & 4.203 \\
\hline \multicolumn{8}{|c|}{ (b) } \\
\hline $\mathrm{Htimb}(\mathrm{m})$ & $q$ total $\left(t / m^{2}\right)$ & $H$ inisial (m) & $\begin{array}{c}\begin{array}{c}H \text { bongkar } \\
(\mathrm{m})\end{array} \\
\end{array}$ & $\mathrm{Sc}(\mathrm{m})$ & $\mathrm{Si}$ & S Total & $H$ final $(\mathbf{m})$ \\
\hline 1 & 3.337 & 2.085 & 0.797 & 0.515 & \begin{tabular}{|l|}
0.0074739 \\
\end{tabular} & 0.523 & 0.766 \\
\hline 2 & 5.195 & 3.290 & 0.797 & 0.882 & $\mid 0.01163347$ & 0.894 & 1.599 \\
\hline 3 & 7.052 & 4.468 & 0.797 & 1.200 & \begin{tabular}{|c|}
0.01579305 \\
\end{tabular} & 1.216 & 2.455 \\
\hline 4 & 8.910 & 5.625 & 0.797 & 1.481 & 0.01995263 & 1.501 & 3.327 \\
\hline 5 & 10.767 & 6.767 & 0.797 & 1.733 & 0.02411221 & 1.757 & 4.212 \\
\hline
\end{tabular}

Hubungan H-Inistial dengan H-Final dan hubungan H-Final dengan Sc pada Tabel 3, dibuatkan grafik yang dapat dilihat pada Gambar 3 dan 4. Grafik tersebut menghasilkan persamaan regresi pangkat 3 yang digunakan menghitung $\mathrm{H}$ Initial, H-Final dan SC.

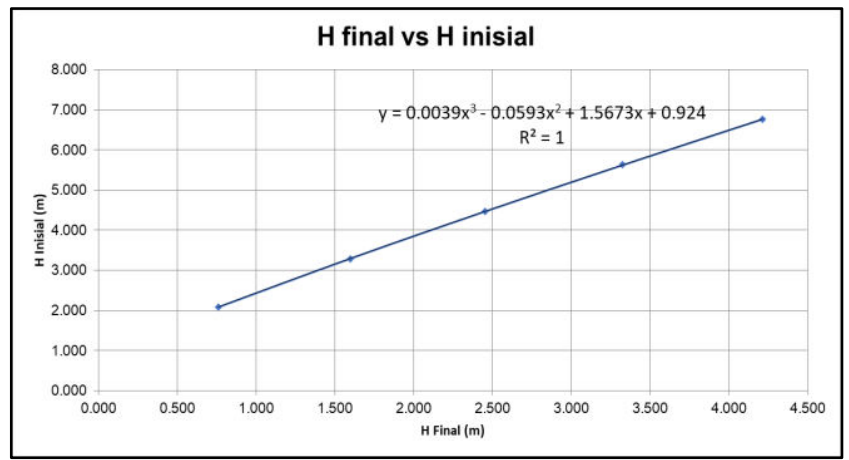

Gambar 3. Grafik Antara H-Final dan H-Inisial Zona 1.

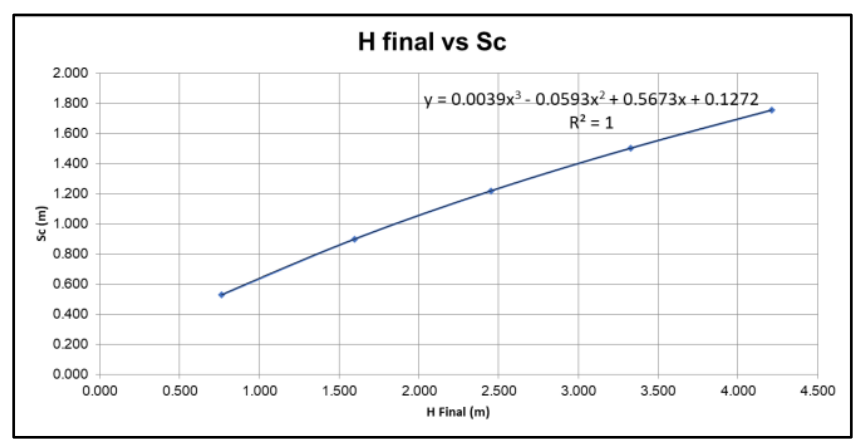

Gambar 4. Grafik Antara H-Final dan Sc Zona 1.

H-Final $=3.06 \mathrm{~m} ; \mathrm{H}$-Initial $=5.28 \mathrm{~m} ; \mathrm{Sc}=1.42 \mathrm{~m}$

Dengan cara yang sama untuk Zona 2 diperoleh

H-Final $=2.56 \mathrm{~m} ; \mathrm{H}$-Initial $=4.59 \mathrm{~m} ; \mathrm{Sc}=1.23 \mathrm{~m}$

Perhitungan Waktu Pemampatan Tanpa PVD

Perhitungan waktu pemampatan dilakukan untuk mengetahui perlu atau tidaknya pemasangan PVD sebagai pemercepat waktu pemampatan. Hasil perhitungan pada [1] diperoleh $\mathrm{Cv}$ gabungan sebesar $1.791 \mathrm{~m}^{2} /$ tahun dan tebal lapisan drainage (Hdr) sebesar $11 \mathrm{~m}$ karena terdapat lapisan pasir dibawah tanah mampu mampat, sehingga air pada lapisan tersebut dapat mengalir ke atas dan ke bawah, maka nilai Hdr dibagi 2.

Perencanaan PVD

PVD direncanakan dengan pemasangan pola segiempat dengan spasi $1.2 \mathrm{~m}$ dengan derajat konsolidasi sebesar 90.58 $\%$ yang dicapai selama 23 minggu. Grafik yang ditunjukkan pada Gambar 5 yaitu hubungan $\bar{U}$ dengan waktu yang dibutuhkan untuk mencapai derajat konsolidasi yang direncanakan.

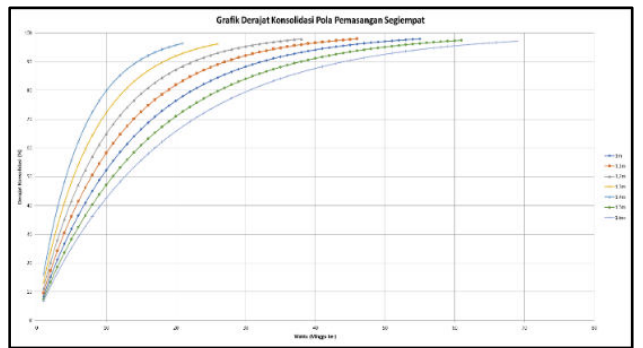

Gambar 5. Grafik Derajat Konsolidasi PVD Pola Pemasangan Segiempat.

\section{Perencanaan PHD}

Penggunaan PHD berfungsi untuk menyalurkan air dari PVD ke saluran drainase di samping kanan atau kiri timbunan. Berdasarkan spesifikasi PHD CETEAU CT-SD100-20 dari brosur memiliki kapasitas pengaliran $2.4 \times 10^{-5} \mathrm{~m}^{3} /$ detik, maka

- Zona 1

$\mathrm{SF}=2.4 \times 10^{-5} \mathrm{~m}^{3} /$ detik $/ 1.69 \times 10^{-5} \mathrm{~m}^{3} /$ detik $=14>1.3(\mathrm{OK})$

\section{- $\quad$ Zona 2}

$\mathrm{SF}=2.4 \times 10^{-5} \mathrm{~m}^{3} /$ detik $/ 7.89 \times 10^{-6} \mathrm{~m}^{3} /$ detik $=30>1.3(\mathrm{OK})$

Sehingga pemasangan PHD CETEAU CT-SD100-20 dapat dilaksanakan pada kedua timbunan.

Penimbunan Bertahap

Penimbunan bertahap dilakukan untuk mempermudah metode pelaksanaan di lapangan. Berdasarkan hasil perhitungan $\mathrm{H}$-Inisial yang didapatkan, maka jumlah tahapan penimbunan untuk Zona 1 adalah 11 minggu dan Zona 2 adalah 10 minggu. Perhitungan tegangan dapat dilakukan sampai tahapan terakhir hingga mencapai H-Inisial karena nilai $\mathrm{H}-$ Kritis $>1$. Setelah itu mencari tegangan $\mathrm{U}=100 \%$, $\mathrm{U}<100 \%$, kenaikan $\mathrm{Cu}$ Baru dan Pemampatan akibat penimbunan bertahap.

\section{Perencanaan Perkuatan Dinding}

Geometri dan Pembebanan Dinding

Perkuatan dinding terbagi menjadi 2 zona yaitu Zona 1 dan Zona 2. Lokasi perkuatan dinding dapat dilihat pada Gambar 6. Kedua zona tersebut memiliki kedalaman galian tanah dasar yang sama yaitu mulai dari elevasi $+1.44 \mathrm{~m}$ hingga $-9 \mathrm{~m}$. Perencanaan dinding dari kedua zona tersebut menggunakan timbunan sebagai beban surcharge. Geometri perencanaan dinding dapat dilihat pada Gambar 7.

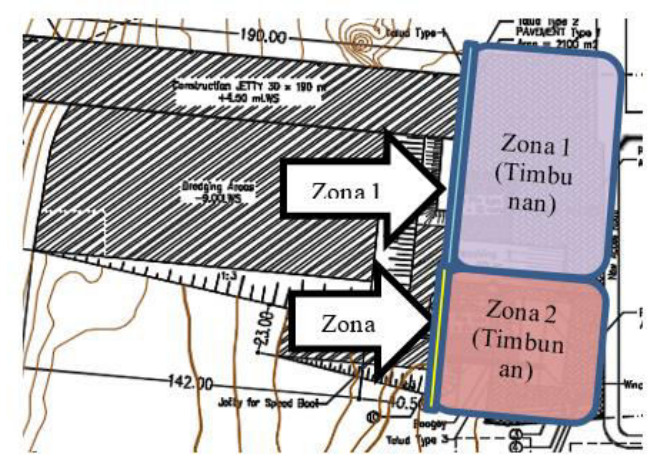

Gambar 6. Lokasi perkuatan dinding. 


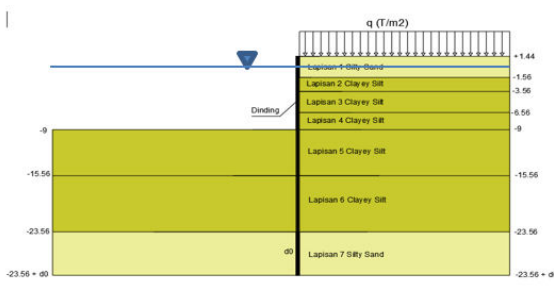

Gambar7. Geometri Perencanaan Dinding.

\section{Perencanaan Dinding Tanpa Angkur}

Sketsa gaya-gaya yang bekerja pada turap ditunjukkan pada Gambar 8. Gaya-gaya tersebut digunakan untuk menghitung persamaan momen $\Sigma \mathrm{M}=0$ dengan titik putar momenya berada pada dasar dinding. Dari kedua persamaan yang didapatkan maka dicari faktor dari persamaan tersebut, dan didapatkan panjang $\mathrm{d} 0$.

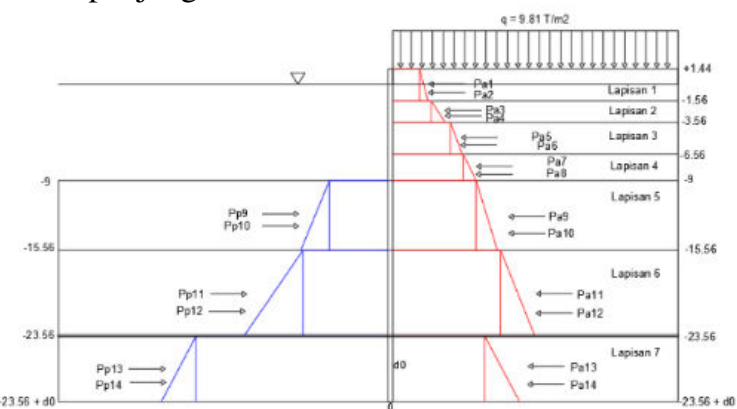

Gambar 8. Sketsa Gaya Horisontal yang Bekerja pada Dinding Tanpa Angkur.

Total panjang dinding yang dibutuhkan adalah

Zona 1: $\mathrm{d}=(19.5 \mathrm{~m} \times 1.2)+25 \mathrm{~m}=48.39 \mathrm{~m}$

Zona 2: $\mathrm{d}=(15.9 \mathrm{~m} \times 1.2)+25 \mathrm{~m}=43.96 \mathrm{~m}$.

Momen maksimum yang bekerja pada turap adalah:

Zona 1: $\mathrm{M}=1427$ ton. $142700000 \mathrm{~kg} . \mathrm{cm}$.

Zona 2: $\mathrm{M}=1011$ ton. $\mathrm{m}=10110000 \mathrm{~kg} . \mathrm{cm}$.

Perencanaan Dinding Dengan Angkur

Untuk mengurangi panjang dinding maka dinding diperlukan angkur. Dengan cara yang sama dengan perhitungan dinding tanpa angkur tetapi titik putar momen berada di posisi angkur.

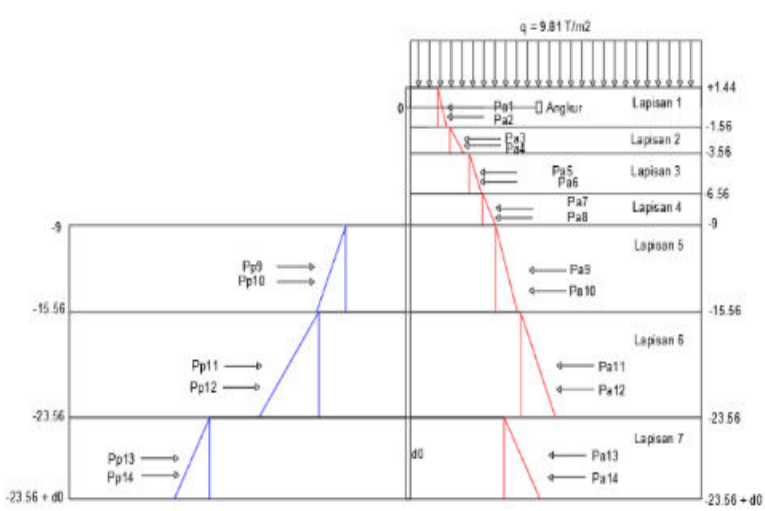

Gambar 9. Sketsa Gaya Horisontal yang Bekerja pada Dinding dengan Angkur.

Momen maksimum yang bekerja pada turap adalah:

Zona 1: $M=1799$ ton. $\mathrm{m}=179900000 \mathrm{~kg} . \mathrm{cm}$.

Zona 2: $M=1679$ ton.m $=167900000 \mathrm{~kg} . \mathrm{cm}$.

Perencanaan Profil Dinding

Berdasarkan hasil perhitungan momen maksimal, diambil momen maksimum yang terbesar. Berikut merupakan perhitungan untuk menentukan profil yang dipakai.

Sheet Pile

Nilai section modulus akibat momen yang bekerja didapatkan dengan membagi Mmax dengan tegangan ijin, yakni sebesar $1500 \mathrm{~kg} / \mathrm{cm}^{2}$, sehingga diperoleh section modulus sebesar

Zona $1=95117.59 \mathrm{~cm}^{3}$

Zona $2=67397.39 \mathrm{~cm}^{3}$

Section modulus profil turap terbesar adalah $25530 \mathrm{~cm}^{3}$. section modulus rencana lebih besar dari section modulus profil, sehingga profil turap tidak dapat digunakan untuk perkuatan dinding pada kedua zona. Selain itu, panjang sheet pile yang tersedia dari pabrik maksimal hanya $21 \mathrm{~m}$, sehingga tidak dapat memenuhi panjang rencana dari dinding.

\section{Secant Pile}

Profil secant pile didapatkan menggunakan program bantu $P C A C O L$ dengan memasukkan input beban, asumsi diameter dan tulangan utama. Berikut merupakan hasil rekapitulasi dari PCA COL:

Zona 1: $\mathrm{d}=1500 \mathrm{~mm}$, tulangan utama 42 D50

Zona 2: $\mathrm{d}=1500 \mathrm{~mm}$, tulangan utama $38 \mathrm{D} 50$

Perhitungan tulangan geser dihitung menggunakan nilai $\mathrm{Vu}$ yang didapat dari $\Sigma$ gaya horizontal dan aktif. Berikut adalah perhitungan tulangan geser untuk kedua zona.

Zona 1: $\mathrm{Vu}=614.939 \mathrm{kN}<\phi \mathrm{Vn}=8470.03 \mathrm{kN}$

Zona 2: $\mathrm{Vu}=461.466 \mathrm{kN}<\phi \mathrm{Vn}=8470.03 \mathrm{kN}$

Nilai $\mathrm{Vu}$ dari kedua zona didapat lebih kecil daripada $\phi \mathrm{Vn}$, sehingga tidak perlu adanya tulangan geser. Namun untuk alasan keamanan tetap direncanakan tulangan geser dengan diameter D16 secara spiral.

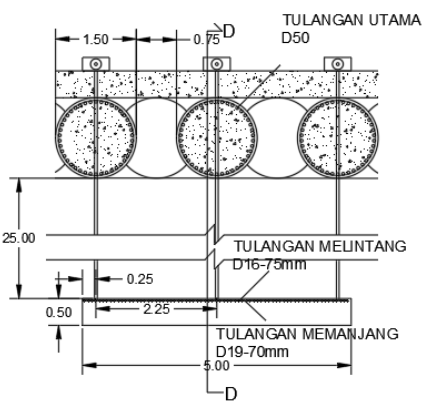

Gambar 10. Sketsa Penampang Profil Secant Pile.

Menentukan Diameter Baja Angker

Zona 1: $\mathrm{T}$ Angkur $=51.24$ ton

Zona 2: $\mathrm{T}$ Angkur $=37.65$ ton

Direncanakan diameter angker

Zona $1 \mathrm{D}=8 \mathrm{~cm}$

Zona $2 \mathrm{D}=7 \mathrm{~cm}$

Menentukan panjang angkur harus terletak pada daerah yang stabil [4]. Sketsa panjang angkur ditunjukkan pada Gambar 11.

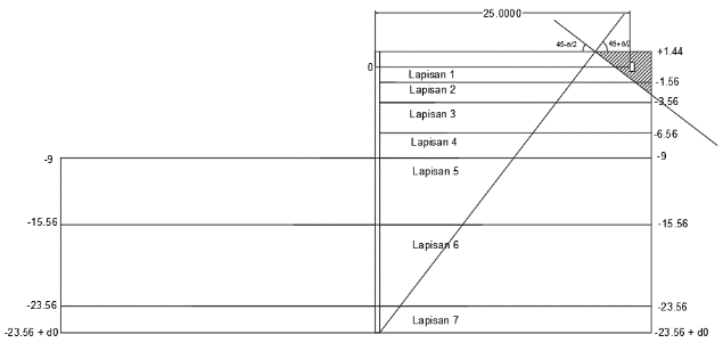

Gambar 11. Sketsa Panjang Angkur.

\section{Perencanaan Angkur}

Angkur direncakan dengan menggunakan metode blok angkur. Perencanaan blok angkur yaitu mencari lebar blok angkur. berikut merupakan hasil perhitugan blok angkur 
Zona 1: B = $5 \mathrm{~m}$; tulangan memanjang D19-70mm; tulangan melintang D16-75mm

Zona 2: $\mathrm{B}=3 \mathrm{~m}$; tulangan memanjang D16-70mm; tulangan melintang D16-75mm

Soldier Pile

Profil soldier pile dapat dihitung melalui section modulus. Berikut diberikan perhitungan kontrol soldier pile

Zona 1: $\mathrm{S}=43867.29194 \mathrm{~cm}^{3}$

Direncanakan soldier pile profil circular hollow dengan spesifikasi

$\mathrm{d} 2=2500 \mathrm{~mm} ; \mathrm{t}=19 \mathrm{~mm}$

$\mathrm{S}$ Circular Hollow $=46104.08798 \mathrm{~cm}^{3}>43867.29194 \mathrm{~cm}^{3}$ (OK)

Zona 2; $\mathrm{S}=40916.74472 \mathrm{~cm}^{3}$

Direncanakan soldier pile profil circular hollow dengan spesifikasi

$\mathrm{d} 2=2500 \mathrm{~mm} \mathrm{t}=19 \mathrm{~mm}$

S Circular Hollow $=46104.08798 \mathrm{~cm}^{3}>40916.74472 \mathrm{~cm}^{3}$ (OK)

Didapatkan profil soldier pile dari kedua zona menggunakan diameter $2500 \mathrm{~mm}$ dengan tebal $19 \mathrm{~mm}$.

Kontrol Lentur

$\phi \mathrm{Mn}=189026810 \mathrm{~kg} . \mathrm{cm}>\mathrm{Mu}=179855897 \mathrm{~kg} . \mathrm{cm}(\mathrm{OK})$

Kontrol Geser

$\phi \mathrm{Vn}=175275000 \mathrm{~kg}>\mathrm{Vu}=614.939 \mathrm{kN}=61493.9 \mathrm{~kg}(\mathrm{OK})$

Pemasangan Angkur menggunakan cara yang sama dengan Secant Pile

Analisis Stabilitas

Analisis stabilitas dilakukan untuk memeriksa safety factor overall stability dan deformasi perkuatan dinding akibat beban yang bekerja pada dinding. Hasil analisis stabilitas dapat dilihat pada Tabel 6 .

Tabel 6.

Hasil Analisis Stabilitas; (a) Secant Pile; (b) Soldier Pile; (c) Deformasi

\begin{tabular}{|c|c|c|c|c|c|c|c|}
\hline \multicolumn{4}{|c|}{ (a) } & \multicolumn{4}{|c|}{ (b) } \\
\hline & Zona 1 & Zona 2 & & & Zona 1 & Zona 2 & \\
\hline SF & 1.501 & 1.552 & & SF & 2.142 & 2.259 & \\
\hline$R$ & 17.628 & 15.871 & $m$ & $R$ & 22.853 & 22.319 & $m$ \\
\hline Mres & 29533 & 23026 & $\mathrm{kNm}$ & Mres & 97448 & 98212 & $\mathrm{kNm}$ \\
\hline$x$ & 38.636 & 39.891 & $\mathrm{~m}$ & $x$ & 29.972 & 30.506 & $\mathrm{~m}$ \\
\hline$y$ & 36.523 & 35.224 & $\mathrm{~m}$ & $y$ & 36.866 & 35.653 & \\
\hline \multicolumn{8}{|c|}{ (c) } \\
\hline & & \multicolumn{2}{|c|}{ Zona } & SF & \multicolumn{3}{|c|}{ Deformasi (m) } \\
\hline \multirow{2}{*}{\multicolumn{2}{|c|}{ Secant Pile }} & & 1 & 1.501 & & & 0.0535 \\
\hline & & & 2 & 1.552 & & & 0.0486 \\
\hline \multirow{2}{*}{\multicolumn{2}{|c|}{ Soldier Pile }} & & 1 & 2.142 & & & 0.0634 \\
\hline & & & 2 & 2.259 & & & 0.0581 \\
\hline
\end{tabular}

Perhitungan Biaya Material untuk Pemilihan Alternatif Perhitungan total kebutuhan dan biaya material dapat dilihat pada tabel 7 .

Tabel 7.

Total Kebutuhan dan Biaya Material; (a) Secant Pile; (b) Soldier Pile (a)

\begin{tabular}{|c|c|c|c|c|c|c|}
\hline \multirow{2}{*}{ No } & \multirow{2}{*}{ Pekerjaan } & \multirow{2}{*}{ Satuan } & \multicolumn{2}{|c|}{ Volume } & \multirow{2}{*}{$\begin{array}{c}\text { Harga Satuan } \\
\text { Rp }\end{array}$} & \multirow{2}{*}{$\begin{array}{l}\text { Jumlah } \\
\text { Rp }\end{array}$} \\
\hline & & & Timbunan 1 & Timbunan 2 & & \\
\hline \multirow[t]{4}{*}{$I$} & Pemasangan PVD dan PHD & & & & & \\
\hline & 1 PVD & $\mathrm{m}$ & 113400 & 58050 & $3,500.00$ & $600,075,000.00$ \\
\hline & 2 PHD & $\mathrm{m}$ & 5471.28 & 2771.28 & $117,000.00$ & $964,379,520.00$ \\
\hline & Sub Total & & & & & $1,564,454,520.00$ \\
\hline & & & & & & \\
\hline \multirow[t]{5}{*}{ III } & Pekerjaan Secant Pile & & & & & \\
\hline & 1 Primary Bor Pile & m3 & 2631.2 & 1196 & $50,000.00$ & $191,360,000.00$ \\
\hline & $\begin{array}{ll}2 & \text { Secondary Bor Pile } \\
\end{array}$ & $\mathrm{m} 3$ & 3498.948818 & $\begin{array}{ll}1625.774198 \\
\end{array}$ & $980,000.00$ & $5,022,228,555.84$ \\
\hline & Sub Total & & & & & $5,213,588,555.84$ \\
\hline & & & & & & \\
\hline \multirow[t]{5}{*}{ III } & Blok Angkur & & & & & \\
\hline & \begin{tabular}{l|l|}
1 & Tendon \\
\end{tabular} & Ton & 17.34011883 & 8.8627274 & $35,910,000.00$ & $940,944,207.99$ \\
\hline & \begin{tabular}{|l|l|}
2 Pelat Beton \\
\end{tabular} & m3 & 281.25 & \begin{tabular}{l|l}
143.75 \\
\end{tabular} & $980,000.00$ & $416,500,000.00$ \\
\hline & Sub Total & & & & & $1,357,444,207.99$ \\
\hline & & & & & otal & $8,135,487,283.83$ \\
\hline
\end{tabular}

(b)
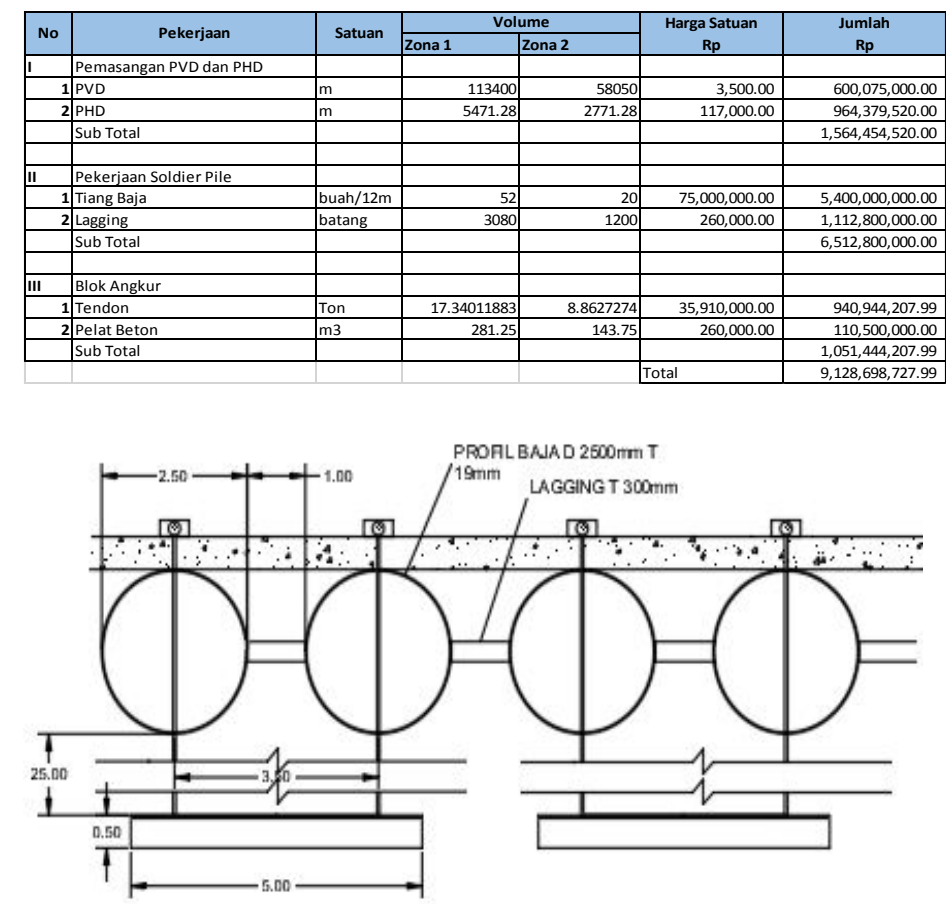

Gambar 12. Sketsa Penampang Profil Soldier Pile Circular Hollow

Perencanaan paling ekonomis adalah perkuatan dinding menggunakan secant pile dengan biaya material total sebesar Rp8.135.487.283,-.

\section{KESIMPULAN}

Dalam perencanaan Tugas Akhir ini didapatkan beberapa kesimpulan yaitu:

1. Berdasarkan hasil analisis didapat kondisi tanah pada kawasan sisi darat proyek pelabuhan RDMP - RU V PT. Pertamina, Balikpapan memiliki tebal lapisan mampu mampat sedalam $25 \mathrm{~m}$ dengan 3 meter awal lapisan tanah silty sand dan 22 meter dibawahnya adalah lapisan tanah clayey silt. Sedangkan kondisi tanah dredging di sisi laut proyek pelabuhan RDMP RU V PT. Pertamina, Balikpapan, yang digunakan untuk material timbunan hingga kedalaman -9 mLws adalah lapisan silty sand.

2. Material yang digunakan untuk timbunan adalah material dredging. Parameter material dredging didapat sebagai berikut:

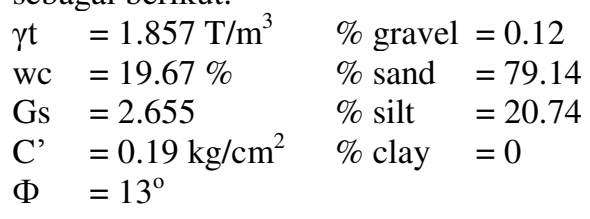

Material timbunan tersebut tidak perlu dilakukan stabilisasi karena sudah memenuhi beberapa syarat material timbunan seperti nilai $\gamma$ lebih besar dari 1.85 $\mathrm{T} / \mathrm{m}^{3}$, prosentase pasir tidak $100 \%$ homogen dan prosentase lempung kurang dari $20 \%$.

3. Tinggi awal timbunan (H-Inisial) yaitu

Di Zona $1=5.28 \mathrm{~m}$ dengan nilai $\mathrm{Sc}=1.42 \mathrm{~m}$

Di Zona $2=4.59 \mathrm{~m}$ dengan nilai $\mathrm{Sc}=1.23 \mathrm{~m}$

4. Waktu pemampatan konsolidasi tanpa PVD untuk mencapai derajat konsolidasi (U) 90\% ditempuh dalam waktu 57.3 tahun. Sedangkan apabila digunakan PVD waktu pemampatan konsolidasi untuk mencapai (U) 90 $\%$ dapat ditempuh dalam waktu 23 minggu. PVD direncanakan dengan pola segiempat dengan spasi 1.2 $\mathrm{m}$ yang ditanam sedalam 25 meter. 
5. Hasil Perencanaan Konstruksi Dinding Penahan Tanah adalah sebagai berikut:

- Sheet pile

Sheet pile tidak dapat digunakan karena section modulus rencana lebih besar dari section modulus profil, sehingga profil turap tidak dapat digunakan untuk perkuatan dinding pada Zona 1 dan 2. Selain itu, panjang sheet pile yang tersedia dari pabrik maksimal hanya $21 \mathrm{~m}$, sehingga tidak dapat memenuhi panjang rencana dari dinding.

- $\quad$ Secant Pile

Di Zona 1

$\mathrm{d}=1500 \mathrm{~mm}$, tulangan utama 42 D50

Di Zona 2

$\mathrm{d}=1500 \mathrm{~mm}$, tulangan utama 38 D50

Nilai Vu dari kedua zona didapat lebih kecil daripada $\phi \mathrm{Vn}$, sehingga tidak perlu adanya tulangan geser. Namun untuk alasan keamanan tetap direncanakan tulangan geser dengan diameter D16 secara spiral.

- $\quad$ Soldier Pile

Didapatkan profil soldier pile dari kedua zona adalah menggunakan profil baja circular hollow dengan diameter $2500 \mathrm{~mm}$ dan tebal $19 \mathrm{~mm}$.

6. Berdarakan hasil perhitungan total kebutuhan dan biaya material, maka dapat diketahui bahwa perencanaan paling ekonomis adalah perkuatan dinding menggunakan secant pile. Biaya material total sebesar Rp8.135.487.283,- dengan kedalaman 27.6 m untuk zona 1 dan 26.3 m untuk zona 2

Saran

Setelah dilakukan analisis dan perhitungan, penulis memberikan saran yaitu:

1. Perlu adanya standar peraturan tentang material dredging yang digunakan sebagai material tanah timbunan sehingga pada saat perencanaan penimbunan hasilnya lebih baik.

2. Perlu adanya metode pelaksanaan yang tepat untuk penggalian dredging dan pemasangan perkuatan dinding yang sesuai kenyataan di lapangan.

\section{DAFTAR PUSTAKA}

[1] M. I. A. Perdana, "Perencanaan Perkuatan Dinding Kolam Pelabuhan dan Penggunaan Material Dredging Sebagai Material Timbunan pada Area Perluasan Dermaga Studi Kasus Proyek RDMP-RU V PT. Pertamina Balikpapan.," Surabaya, 2017.

[2] H. Wahyudi, Teknik Reklamasi. Surabaya: Institut Teknologi Sepuluh Nopember, 1997.

[3] N. E. Mochtar, "Modul Ajar Metode Perbaikan Tanah," Jur. Tek. Sipil, 2012.

[4] Das. Braja M., Principles of Foundation Engineering. Boston: PWS-KENT, 1990. 